\title{
Prediction of Mathematics Learning Strategies on Mathematics Achievement among 8th Grade Students in Jordan
}

\author{
Belal Sadiq Rabab'h ${ }^{1} \&$ Arsaythamby Veloo ${ }^{1}$ \\ ${ }^{1}$ School of Education and Modern Languages, University Utara Malaysia, (UUM), Sintok, Kedah, Malaysia \\ Correspondence: Belal Sadiq Rabab'h, School of Education and Modern Language, University Utara Malaysia, \\ 06010 Sintok, Kedah, Malaysia. E-mail: Belal.Rababh@yahoo.com
}

Received: September 17, 2014

Accepted: October 28, 2014 Online Published: December 20, 2014

doi:10.5539/ass.v11n2p276

URL: http://dx.doi.org/10.5539/ass.v11n2p276

\begin{abstract}
The study aimed to examine the extent of the student's Mathematics Learning Strategy (MLS) factors such as mathematics attitude, mathematics motivation, mathematics self regulation, mathematics self efficacy and mathematics anxiety contribution to mathematics achievement (MA). The respondents of the study were 360 students from eight public middle schools in Jordan selected through stratified random sampling. The study used 65 items to assess the MLS. Moreover, the mathematics test (MAT) comprises 30 items. The results of multiple regression analysis showed that mathematics attitude, mathematics motivation, mathematics self regulation, mathematics self efficacy significantly contributed to MA, with the exception of mathematics anxiety that was found to have an insignificant effect on MA. Educators, principals and teachers should focus on most MLS factors in classes and students should be motivated to understand that the subject could be studied and passed just like other subjects, and to appreciate that it is an essential tool and a prerequisite for further education in many vocations.
\end{abstract}

Keywords: mathematics attitude, mathematics motivation, mathematics self-regulation, mathematics self efficacy, mathematics anxiety, mathematics achievement

\section{Introduction}

Owing to the significance of mathematics in the knowledge economy, Jordan's Ministry of Education (MoE) has been concentrating on improving students' knowledge, skills and achievement in mathematics (Sabah \& Hammouri, 2010). Just recently, an interest has sparked in a method of learning and teaching mathematics that assists students' realization of the mathematics learning process. This interest is evident throughout the approach of teaching the subject. Prior to the said development, the teachers aimed to teach the information for students to be able to solve mathematical problems but following the development, teaching is centered on the development of students' capability of tackling mathematical problems through questions whose solutions lie in the use of specific data and mathematical diagrams to bring about the organization, analysis and delivery of mathematical ideas, to develop the right surrounding that encourages thinking, to help students recall prior experience and to incorporate them with learning skills. These learning skills assist them in reasoning, perceiving and connecting the links between the problem elements and their past experience while solving mathematical problems.

\section{Literature Review}

\subsection{Attitude and Mathematics Achievement}

Mathematics Attitude is defined as a general emotional nature toward the school subject of mathematics. Attitude towards mathematics has a key role in both teaching and learning mathematics and accordingly, it influences mathematics achievement. In this regard, developing positive attitudes towards mathematics maximizes the achievement of students (Bloom, cited in Yaratan \& Kasapoglue, 2012). On the contrary, negative attitudes towards mathematics and lack of motivation leads to low performance. McCleod (1992) stated that mathematics attitude is linked to MA in the classroom. Hence, mathematics attitude has a key role in mathematics learning and teaching. In addition, it impacts student's MA. According to Shashaani (1995), attitudes toward mathematics are significant in the students' achievement and participation in the subject. The attitude towards math should be considered as a predisposition in either a favorable or an unfavorable way to mathematics (Moenikia \& Zahed-Babelan, 2010). 
Jordanian students have been showing poor achievement in mathematics through the four periods $(1999,2003$, 2007, and 2011) in Trends in International Mathematics and Science Study TIMSS (Mullis et al., 2012). According to Hammouri (2004), poor achievement in mathematics among Jordanian middle school students is related to their attitude toward mathematics. He found significant positive impact of attitude towards math on the students' achievement in mathematics. In a related study, Tapia and Marsh (2001) examined the correlation between students' attitude and mathematics success. They brought up the impact of attitude on students' inclination to engage in math activities and the degree of their mathematics attainment. Additionally, they stressed that students do not completely understand the concepts taught to them but attempt at associating what they learn with their experiences. Nasser and Birenbaum (2004) similarly examined the relationship between MA and mathematics attitude. This study carried out the study in two samples $-8^{\text {th }}$ graders Arabs and Jews. They revealed that attitudes insignificantly impacted MA of Jewish students while it significantly impacted the Arab students. In other words, Arab students who exhibited positive attitudes towards the subject gained higher achievement compared with those who displayed negative attitudes. In another study, Nicoladou and Philippou (2003) revealed a significant correlation between mathematics attitude and problem solving achievement. In addition, Ajayyi, Lawani and Adeyanju (2013) investigated the impact of mathematics attitude and self concept concerning math achievement among a total of 2400 Nigerian school students. They revealed that attitude towards the subject significantly impacts mathematics achievement. Furthermore, Manoah, Indoshi and Othuon (2011) examined attitudinal influence upon students' mathematics achievement. They conducted the study among 2960 secondary school students enrolled in Kisumu East District in Kenya. They revealed that mathematics attitude for both girls and boys had a significant effect on mathematics achievement. In addition, Arslan, Carli and Sabo's (2012) study aimed to determine whether any differences exist between female and male students' attitudes and successes of middle school toward mathematics. The findings showed differences between female and male students in light of their achievements in mathematics with the female students outperforming their male counterparts. On other hand, they revealed that mathematics attitude impacted $6-8^{\text {th }}$ graders' mathematics' achievement.

\subsection{Motivation and Mathematics Achievement}

Researchers and academicians alike have been increasingly focused on the topic of motivation in the past years. According to Green (2002), motivation is primarily the individual's state that drives and maintains behavior and on the basis of self-determination theory, motivation is divided into two primary kinds namely intrinsic and extrinsic motivation (Grolnick, Deci, \& Ryan, 1997). The former type of motivation refers to an innate, inclination of the individual to examine and master his internal and external environment (Ryan, Connell, \& Grolnick, 1992) while the latter type of motivation refers to behaviors motivated by the desire to achieve external rewards or social demands (Ryan, Connell, \& Grolnick, 1992). Several factors were examined by Shores and Shannon (2007) according to their role in the students' mathematics attitude and motivation is one of them. They showed that factors of intrinsic motivation correlated with mathematics attitude. In a more recent study, Areepattamannil (2014) studied the intrinsic and extrinsic motivation-mathematics attitude relationship in a sample comprising 363 Indian adolescents and 355 Indian immigrants living in Canada. He revealed that both motivation types and motivation in general were not statistically and significantly associated with mathematics achievement among Indian adolescents. Contrary to this finding, he also found that both motivation types and motivation are statistically and significantly associated to mathematics achievement among the immigrants. Another related study examined the students' mathematics attitude towards mathematics-mathematics achievement relationship as well as their learning motivation-mathematics achievement relationship. A positive significant relationship was revealed in both associations.

\subsection{Self-regulation and Mathematics Achievement}

Elias and MacDonald (2007) stated that self regulation explains how a person controls and directs his or her own actions. Self regulation is closely related to the self assessment skills that involve a high level of self awareness and help students in monitoring their learning and performance. In relation to this, Otts (2010) studied the relationship between students' self-regulation strategies and their attitude towards math and the course outcomes in mathematics development. The regression test showed that self regulated learning and attitude towards math are significant factors and predictors of students achievement in mathematics. In a study of the same caliber, Mousoulides and Philippou (2005) examined the relationships between motivational beliefs, self regulation strategies use, and mathematics achievement. They developed a model depicting connections and causal relations among cognitive and affective factors, which was tested on the basis of self report data collected from 194 respondents using a modified version of MSLQ and a mathematics achievement test. They found that the model explains the structure of the above relationships, with self-efficacy being a strong predictor of 
mathematics achievement and self-regulation strategies use having a negative effect on mathematics achievement. Self-regulation was also studied by Loong (2012) in the context of Malaysian local and international students. He demonstrated that subscales of both attitude and self-testing predicted local students' performance in terms of mathematics, whereas attitude and test strategy subscales significantly predicted their international counterparts' performance in mathematics.

\subsection{Self-efficacy and Mathematics Achievement}

Self-efficacy is described as the beliefs of the students of their ability to achieve a task (Pintrich \& de Groot, 1990). In this regard, self-efficacious students are confident of their ability to achieve actions needed to tackle ambiguous, unpredictable and stressful situations (Bandura, 1986). Tang and Neber (2008) claimed that self-efficacy represents the learners' subjective belief in their own competence for high domain specific achievements. In other words, self-efficacy is a self-assessment belief concerning ones' ability to master a task, whether easy or difficult, and to produce positive outcomes. According to Schunk (1989), self-efficacy can influence a student to choose what kind of activities to get involve in. Activity that needs more cognitive skills will attract higher self efficacious students, but students who have low sense of efficacy tend to avoid it. Self-efficacious students are more successful in performing academic tasks and are more inclined to challenge themselves with difficult tasks and they are motivated to employ various strategies for task achievement. They are also more accurate in mathematical calculations and display higher persistence in solving problems compared to their low-efficacious counterparts (Pajares \& Graham, 1999). In a related study, Nicolaidou and Philippou (2003) explored the relationships between students' attitudes towards mathematics self efficacy in problem solving and achievement. They showed a significant relationship between attitudes and achievement and stronger relationship between self efficacy and achievement. They also showed that both attitudes and efficacy are correlated and are predictors of achievement in terms of solving problems, although self efficacy is more powerful predictor than attitude. According to some researchers, self efficacy is a significant predictor of students' future MA (Parker, Marsh, Ciarrochi, Marshall, \& Abduljabbar, 2014). Finally, Watts (2011) studied the predictor factors of mathematics success and found self efficacy in mathematics to be the only predictor of achievement.

\subsection{Anxiety and Mathematics Achievement}

Mathematics anxiety involves tense and anxious feelings when dealing with mathematical problems in daily life and in academic environment (Richardson \& Suinn, 1972). Such anxiety may lead to forgetting and losing confidence in one's self (Tobias, 1993) and it could prevent mathematics achievement (Cooper \& Robinson, 1991). Mathematics anxious students are often stressed when performing mathematical calculations and they display mathematics avoidance, emotional arousal and low cognitive processing while solving math problems (Ashcraft, 2002). In other words, these reactions prevent the successful mathematics learning by students. Anxiety related to mathematics is also found to be directly associated with the students' belief concerning their ability in math and their performance (Meece, Wigfield, \& Eccles, 1990). Mathematics anxious students almost always experience tension and stress and these make them steer clear of mathematics in school, and in turn, both performance and achievement are adversely affected. Cates and Rhymer (2003) studied the mathematics anxiety, fluency, and error rates in basic mathematical operation relationship and showed correlation between mathematics anxiety and basic mathematical operation. Also, Karimi and Venkatesh (2009) attempted to study the level of mathematics anxiety and MA relationship. Their findings revealed that mathematics anxiety has significant negative correlation with mathematics achievement. A similar result was revealed by Ovez (2012) study when he examined the relationship between mathematics anxiety and MA among $2445^{\text {th }}-8^{\text {th }}$ graders in Sindirgi District, Balikesir Province, Turkey. In a related study, Joseph (2012) studied the students' five psych-academic variables and their role as predictors of students' mathematics achievement. The study sample consisted of $8549^{\text {th }}$ graders from secondary school in Nigeria. The findings revealed anxiety not to be a significant predictor of students' mathematics achievement. Additionally, Birgin, Baloglu, Catlioglu, and Gurbuz (2010) investigated mathematics anxiety among 220 Turkish students of $6^{\text {th }}-8^{\text {th }}$ grades in light of their achievement levels in Math, perceived enjoyment of math teaching method and perceived help from parents. According to their findings, mathematics anxiety increased with the students move from a grade to the next. They revealed that mathematics anxiety is at its lowest among students in grade 6 and it is at its highest among $8^{\text {th }}$ graders.

\section{Objective of the Study}

To determine to what extent the student's Mathematics Learning Strategy factors such as mathematics attitude, mathematics motivation, mathematics self regulation, mathematics self efficacy and mathematics anxiety 
contribute to MA?

\section{Methodology}

\subsection{Population and Sample}

The present study was carried out in middle schools in Jordan, specifically in Al-koura District, North of Jordan. The research population sample selected for the present study included $2,2578^{\text {th }}$ grade students $(1,101(49 \%)$ males and $1,156(51 \%)$ females) representing the whole schools (37) in the region. according to Krejcie and Morgan (1970), it is appropriate to select a minimum sample of 331 students from the entire research population. The sample comprised of 360 school students from $8^{\text {th }}$ grade, with $178(49 \%)$ male and $182(51 \%)$ female. This ensured that the number represented the whole population and schools.

\subsection{Instrument}

Data for the study were collected by two instruments - MLS questionnaire and mathematics achievement test. MLS questionnaire is divided into five sections (1-5), and a total of sixty-five items were used to measure factors such as mathematics attitude (18 items), mathematics motivation (7 items), mathematics self regulation (25 items), mathematics self efficacy (5 items) and mathematics anxiety (10 items). Students were asked to indicate the extent to which they agreed with statements on a 5-point Likert scale (choice 1 (strongly disagree), 2 (disagree), 3 (moderately agree), 4 (agree) and 5 (strongly agree)).

The Mathematics Achievement Test (MAT) is a modified and constructed version prepared by the Ministry of Education, Jordan. MAT employed in this study consisted of 30 multiple choice questions, divided into eight items for numbers, fourteen items for algebra and eight items for geometry, of one mark each. A correct response to an item was awarded one mark while an incorrect response was given no mark.

Data collected was analyzed with the help of Statistical Package for Social Sciences (SPSS), version 19.0, in order to examine the obtained information from the respondents.

\section{Results}

The primary purpose of this study is to determine the extent of the students' MLS factors contribution to MA.The MLS factors (Mathematics attitude, Mathematics Motivation, Mathematics self-efficacy, Mathematics self-regulation, and mathematics anxiety) were found to be significantly associated with overall MA. Among the five predictors, Mathematics Attitude $(\beta=.47, \mathrm{t}=2.77, \mathrm{p}<0.05)$ had the highest and significant standardized beta coefficient, which indicates that it was the most important factor contributing to MA. The next important MA contributor was self efficacy $(\beta=0.36, \mathrm{t}=2.05, \mathrm{p}<0.05$ ). On other hand, mathematics motivation and mathematics self regulation had negative regression coefficients $(\beta=-0.63, \mathrm{t}=-2.61, \mathrm{p}<0.05)(\beta=-0.14, \mathrm{t}$ $=2.08, \mathrm{p}<0.05)$ respectively while mathematics anxiety was not significantly related to the overall achievement of mathematics.

Table 1. Multiple regression result between MLS factors and MA

\begin{tabular}{llllll}
\hline $\mathrm{R}$ & $\mathrm{R}^{2}$ & Adjusted $\mathrm{R}^{2}$ & Std. Error Est. & $\mathrm{F}$ & $\mathrm{P}$ \\
\hline 0.291 & 0.09 & 0.070 & 4.80 & 6.00 & $.00^{*}$ \\
Model & Un-Std Beta & Std. Error & Std Beta & $\mathrm{T}$ & $\mathrm{P}$ \\
(Constant) & 11.19 & 1.59 & & 7.03 & .00 \\
Attitude & 4.26 & 1.53 & .47 & 2.77 & $.00^{* *}$ \\
Motivation & -4.58 & 1.75 & -.63 & -2.61 & $.00^{* *}$ \\
Self-regulation & -1.14 & .55 & -.14 & -2.08 & $.03^{*}$ \\
Self-efficacy & 1.98 & .96 & .36 & 2.05 & $.04^{*}$ \\
Anxiety & 1.38 & .84 & .19 & 1.64 & .10 \\
\hline
\end{tabular}

a. Dependent Variable: Mathematics achievement

\section{Model of MLS and MA}

$\mathrm{MA}=11.19+4.26$ Attitude -4.58 Motivation -1.14 Self-Regulation +1.98 Self-Efficacy +1.38 Anxiety $+\mathrm{e}$ $\mathrm{t}=2.77^{*} ; \mathrm{t}=-2.61^{*} ; \mathrm{t}=-2.08^{*} ; \mathrm{t}=2.05^{*} ; \mathrm{t}=1.64^{*}$

The result of this study showed that the relationship between mathematics attitude and MA is positive and 
significant $(\mathrm{t}=4.26, \mathrm{p}<0.05)$. This means that as the mathematics attitude increases, the level of MA also increases. The result also showed that mathematics motivation and mathematics self-regulation are both significantly and negatively associated with MA $(\mathrm{t}=-2.61, \mathrm{p}<0.05)$ and $(\mathrm{t}=4.26, \mathrm{p}<0.05)$ respectively. Moreover, the relationship between mathematics self-efficacy and MA is positive and significant $(\mathrm{t}=1.98, \mathrm{p}<$ 0.05). On the other hand, a significant and negative relationship was found between MA and mathematics self-regulation $(\mathrm{t}=-2.08, \mathrm{p}<0.05)$. In addition, mathematics anxiety was found not to be significantly associated with MA and its $(\mathrm{t}=1.64, \mathrm{p}>0.05)$. The formula below shows the model of the present study $(\mathrm{a} \& \mathrm{~b})$.

$$
\begin{gathered}
\text { a. MA }=11.19+4.26 \text { Attitude }-4.58 \text { Motivation }-1.14 \text { Self-Regulation }+1.98 \text { Self-Efficacy }+1.38 \text { Anxiety }+\mathrm{e} \\
\mathrm{t}=2.77^{*} \quad \mathrm{t}=-2.61^{*} \quad \mathrm{t}=-2.08^{*} \quad \mathrm{t}=2.05^{*} \quad \mathrm{t}=1.64 \\
\text { b. MA }=11.19+4.26 \text { Attitude }-4.58 \text { Motivation }-1.14 \text { Self-Regulation }+1.98 \text { Self-Efficacy }+\mathrm{e}
\end{gathered}
$$

\section{Discussion and Conclusion}

Mathematics attitude was found to be related to the overall achievement of mathematics. In other words, the level of achievement in overall MA may depend on the student's attitude towards mathematics. A positive attitude towards mathematics may lead to higher level of overall achievement in the subject. The finding is consistent with Marsh and Tapia (2001) who found that MA of students was strongly and positively influenced by student attitude. They reported the impact of attitude on students' inclination to engage in math activities and the degree of their mathematics attainment. This is also in line with Ajayyi et al. (2013), and Arslan et al. (2012) who stated that mathematics attitude have significant joint effect on MA. The reason behind the present study's result is attributed to the fact that mathematics is more likely to be taught in school than any other subject. In addition, the students' attitudes towards mathematics were positive and that many of them believed that mathematics is a valuable and necessary subject which can help them in their future life. Therefore, students may perceive the importance of mathematics as it is strongly relevant to their lives. Furthermore, teaching materials used by teachers, content knowledge and personality as well as factors from the home environment and society also affect the relationship between attitude and MA. Moreover, this study finding indicates that the statistical significance of mathematics attitude and MA is in line with studies, including Nasser and Birenbaum (2005) and Manoah et al. (2011).

Motivation was found to negatively influence overall achievement of mathematics. Motivation in this study was revealed to be significantly related with MA, which is consistent with the findings of Shores and Shanon (2007) who reported that student's motivation influenced MA. Motivation is the most evident learning factor that directly affects the success of the students in mathematics subject (Gottfried, Fleming, \& Gottfried, 2001). A possible explanation for the effect of motivation on MA is that students generally place more value on engaging in academic activities than in mathematics subject and hence, the quality of their engagement is less valuable. Furthermore, it could be attributed to the similarity in their cognitive stage of development. In addition, instructors may still be using traditional teaching methods and strategies, which make mathematics learning inactive and in turn, lower the students' interest to learn the subject.

Self regulation was found to negatively affect students' MA. In this study, self-regulation reflects the level of students' concentration and their use of self-testing, study's aids and time management. Otts (2010) reported that implemented self-regulation strategies linked to teaching approach would affect the output of mathematics among students in terms of their achievement. Possible explanation for this study result is that students are generally not trained to use self-regulation strategies during regular classes. Furthermore, the instructor may not ensure a direct transfer of self-regulation strategies to the subject related tasks on mathematics. Consequently, the students are less motivated and less persistent to achieve their tasks related to mathematics subject.

Another important finding is related to self-efficacy. In this study, the term self-efficacy refers to the students' judgments about their ability to successfully accomplish a task, as well as to a student's confidence in his/her skills to perform that task (Pintrich et al., 1993). The present study found significant influence of self-efficacy on MA. This finding is consistent with Watts (2011) and Shores and Shanon (2007) who stated that mathematics self efficacy predicts mathematics achievement. The result may be attributed to the strong inter-correlation between self-efficacy and MA. Another possible explanation could be that students were confident to do excellent performance in math, they understood the most difficult materials presented in math classes, and they do excellent job on mathematics assignments and master skills being taught in their math classes and consequently, students tend to have higher confidence in performing mathematical tasks. Thus, the result of the influence of self-efficacy on MA was supported in the present study.

Finally, this study revealed that another MLS factor, namely mathematics anxiety has insignificant effect on MA. 
The insignificant outcome of the hypothesis is in line with the studies of Joseph (2012) who reported that anxiety did not significantly predict students' MA. On other hand, the result of the present study contradicted with other previous studies (Birgin et al., 2010; Ovez's, 2012) who found that mathematics anxiety is a significant predictor of math outcome. This result may be attributed to the fact that mathematics anxiety was fairly stable over the short period of data collection. Therefore, the insignificant result of this study is justified.

\section{Implication}

This study attempts to present MLS factors that affect student's mathematics achievement. Additionally, the current study was the pioneer in examining MLS factors in a single model. The findings from the present analysis revealed empirical partial consistency with the previous studies claiming that some of the MLS factors affected student's mathematics achievement.

It has been shown through this study that mathematics attitude is the most powerful predictor of mathematics achievement among eighth grade students in Jordanian schools. Therefore, the teachers have to pay attention to math and consider it as one of the important and necessary materials in school and everyday life. This could be done through the development of students' skills in mathematics knowledge in its various aspects, using suitable techniques and teaching methods for making mathematics interesting subject and attractive for the students.

Self efficacy is considered the second factor in terms of the prediction of mathematical achievement and thus teachers must provide mathematical concepts in easy and simplified ways so that the students could understand the content and educational material provided. In addition, the teachers could praise and reward students after doing homework and tasks entrusted to them in classrooms. The anxiety in mathematics is considered one of the factors, which could cause low achievement in mathematics. However, the current findings indicate a lack of anxiety concern among the students during the learning of math and this could be positive indicator, as it becomes easy to deal with the problems faced by the students in achievement and learning math.

The present study showed that student's mathematics achievement was affected by the MLS factors. Therefore, the school management and academic staff should take into account the important role of these factors in enhancing the student's mathematics achievement.

\section{Conclusion}

This study found that MLS factors such as mathematics attitude, mathematics motivation; mathematics self-efficacy and mathematics self-regulation are predictors of mathematics achievement. However, mathematics anxiety was not significantly found to be related to the overall achievement of mathematics. The main recommendations from this study are for teachers and other educational professionals to focus on the mathematics learning strategy to improve the learning of mathematics. Students at middle schools in Jordan should be motivated to understand that mathematics could be studied and passed just like other subjects, and to appreciate that the subject is an essential tool, a prerequisite for further education and in many vocations.

\section{References}

Ajayi, K. O., Lawani, A. O., \& Adeyanju, H. I. (2013). Effects of Students' Attitude and Self-Concept on Achievement in Senior Secondary School Mathematics in Ogun State, Nigeria. Journal of Research in National Development, 9(2), 202-211.

Areepattamannil, S. (2014). Relationship between Academic Motivation and Mathematics Achievement Amon Indian Adolescents in Canada and India. The Journal of General Psychology, 141(3), 247-262. http://dx.doi.org/10.1080/00221309.2014.897929

Arslan, H., Carli, M., \& Sabo, M. (2012). A research of the effect of attitude, achievement, and gender on mathematics education. Acta Didactica Napocensia, 5(1), 45-52.

Ashcraft, M. H. (2002). Cognition. London: Prentice Hall.

Bandura, A. (1986). Social Foundations of Thought and Action: A Social Cognitive Theory. Englewood Cliffs, NJ: Prentice-Hall.

Birgin, O., Baloglu, M., Catlioglu, H., \& Gurbuz, R. (2010). An investigation of mathematics anxiety among sixth through eighth grade students in Turkey. Learning and Individual Differences, 20(6), 654-658. http://dx.doi.org/10.1016/j.lindif.2010.04.006

Cates, G. L., \& Rhymer, K. N. (2003). Examining the relationship between mathematics anxiety and mathematics performance: An instructional hierarchy perspective. Journal of Behavioral Education, 12(1), 23-34. http://dx.doi.org/10.1023/A:1022318321416 
Cooper, S. E., \& Robinson, D. A. G. (1991). The relationship of mathematics self-efficacy beliefs to mathematics anxiety and performance. Measurement and Evaluation in Counseling and Development, 24(1), 4-11.

Elias, S. M., \& MacDonald, S. (2007). Using Past Performance, Proxy Efficacy, and Academic Self-Efficacy to Predict College Performance. Journal of Applied Social Psychology, 37(11), 2518-2531. http://dx.doi.org /10.1111/j.1559-1816.2007.00268.x

Gottfried, A. E., Fleming, J. S., \& Gottfried, A. W. (2001). Continuity of academic intrinsic motivation from childhood through late adolescence: A longitudinal study. Journal of Educational Psychology, 93(1), 3-13. http://dx.doi.org/10.1037/0022-0663.93.1.3

Green, S. K. (2002). Using an Expectancy-Value Approach to Examine Teachers' Motivational Strategies. Teaching and Teacher Education, 18(8), 989-1005. http://dx.doi.org/10.1016/S0742-051X(02)00055-0

Grolnick, W. S., Deci, E. L., \& Ryan, R. M. (1997). Internalization within the family: The self-determination theory perspective. In J. E. Grusec, \& L. Kuczynski (Eds.), Parenting and children's internalization of values: A handbook of contemporary theory (pp. 135-161). New York: Wiley.

Hammouri, H. (2004). Attitudinal and motivational variables related to mathematics achievement in Jordan: Findings from the Third International Mathematics and Science Study (TIMSS). Educational Research, 46(3), 241-257. http://dx.doi.org/10.1080/0013188042000277313

Joseph, E. (2012). Psych-Academic variables and mathematic achievement of 9th grade students in Nigeria. British Journal of Education, Society \& Behavioral Science, 2(2), 174-183. http://dx.doi.org/10.9734/ BJESBS/2012/1091

Karimi, A., \& Venkatesan, S. (2009). Mathematics anxiety, mathematics performance and academic hardiness in high school students. International Journal of Educational Sciences, 1(1), 33-37.

Krejcie, R. V., \& Morgan, D. W. (1970). Determining sample size for research activities. Educational and Psychological Measurement, 30(3), 607-610.

Loong, T. E. (2012). Self-Regulated Learning Strategies and Pre-University Math Performance of International Students in Malaysia. Journal of International Education Research (JIER), 8(3), 223-232.

Manoah, S. A., Indoshi, F. C., \& Othuon, L. O. (2011). Influence of attitude on performance of students in mathematics curriculum. Educational Research, 2(3), 965-981.

McLeod, D. (1992). Research on affect in mathematics education: A reconceptualization. In D. A. Grouws (Ed.), Handbook of research on mathematics teaching and learning (pp. 575-596). New York: Macmillan.

Meece, J. L., Wigfield, A., \& Eccles, J. S. (1990). Predictors of math anxiety and its influence on young adolescents' course enrollment intentions and performance in mathematics. Journal of educational psychology, 82(1), 60-70. http://dx.doi.org/10.1037/0022-0663.82.1.60

Moenikia, M., \& Zahed-Babelan, A. (2010). A study of simple and multiple relations between mathematics attitude, academic motivation and intelligence quotient with mathematics achievement. Procedia-Social and Behavioral Sciences, 2(2), 1537-1542. http://dx.doi.org/10.1016/j.sbspro.2010.03.231

Mousoulides, N., \& Philippou, G. (2005). Students' motivational beliefs, self-regulation strategies and mathematics achievement. In Proceedings of the 29th Conference of the International Group for the Psychology of Mathematics Education (Vol. 3, pp. 321-328).

Mullis, I. V., Martin, M. O., Foy, P., \& Arora, A. (2012). TIMSS 2011 International Results in Mathematics. International Association for the Evaluation of Educational Achievement. Herengracht 487, Amsterdam, 1017 BT, The Netherlands.

Nasser, F., \& Birenbaum, M. (2005). Modeling mathematics achievement of Jewish and Arab eighth graders in Israel: The effects of learner-related variables. Educational Research and Evaluation, 11(3), 277-302. http://dx.doi.org/10.1080/13803610500101108

Nicolaidou, M., \& Philippou, G. (2003). Attitudes towards mathematics, self-efficacy and achievement in problem solving. European Research in Mathematics Education III. Pisa: University of Pisa.

Otts, C. D. (2010). Self regulation and Math Attitudes: Effects on Academic Performance in Developmental Math Courses in at Community College. (Doctoral dissertation).

Ovez, F. (2012). An examination on the relationship between mathematics anxiety and achievement of $5^{\text {th }}, 6^{\text {th }}, 7^{\text {th }}$ and $8^{\text {th }}$ grade students. International Mathematical Forum, 7(60), 2987-2994. 
Pajares, F., \& Graham, L. (1999). Self-efficacy, motivation constructs, and mathematics performance of entering middle school students. Contemporary Educational Psychology, 24(2), 124-139. http://dx.doi.org/10.1006 /ceps.1998.0991

Parker, P. D., Marsh, H. W., Ciarrochi, J., Marshall, S., \& Abduljabbar, A. S. (2014). Juxtaposing math self-efficacy and self-concept as predictors of long-term achievement outcomes. Educational Psychology, 34(1), 29-48. http://dx.doi.org/10.1080/01443410.2013.797339

Pintrich, R. R., \& DeGroot, E. V. (1990). Motivational and self-regulated learning components of classroom academic performance. Journal of Educational Psychology, 82(1), 33-40. http://dx.doi.org/10.1037/00220663.82.1.33

Richardson, F. C., \& Suinn, R. M. (1972). The Mathematics Anxiety Rating Scale: Psychometric data. Journal of counseling Psychology, 19(6), 551-554. http://dx.doi.org/10.1037/h0033456

Ryan, R. M., Connell, J. P., \& Grolnick, W. S. (1992). When achievement is not intrinsically motivated: A theory of internalization and self-regulation in school. In A. K. Boggiano, \& T. S. Pittman (Eds.), Achievement and motivation: A social-development perspective (pp. 167-188). Cambridge; New York: Cambridge University Press.

Sabah, S., \& Hammouri, H. (2010). Does subject matter? Estimating the impact of instructional practices and resources on student achievement in science and mathematics: findings from TIMSS 2007. Evaluation \& Research in Education, 23(4), 287-299. http://dx.doi.org/10.1080/09500790.2010.509782

Schunk, D. H. (1989). Self-efficacy and achievement behaviors. Educational Psychology Review, 1(3), 173-208. http://dx.doi.org/10.1007/BF01320134

Shashaani, L. (1995). Gender differences in mathematics experience and attitude and their relation to computer attitude. Educational Technology, 35(3), 32-38.

Shores, M. L., \& Shannon, D. M. (2007). The Effects of Self-Regulation, Motivation, Anxiety, and Attributions on Mathematics Achievement for Fifth and Sixth Grade Students. School Science and Mathematics, 107(6), 225-236. http://dx.doi.org/10.1111/j.1949-8594.2007.tb18284.x

Tang, M., \& Neber, H. (2008). Motivation and self-regulated science learning in high-achieving students: Differences related to nation, gender, and grade-level. High Ability Studies, 19(2), 103-116. http://dx.doi.org/10.1080/13598130802503959

Tapia, M., \& Marsh, G. E. (2001). Effect of gender, achievement in mathematics, and grade level on attitudes toward mathematics. Paper presented at the Annual Meeting of the Mid-South Educational Research Association. Science, Mathematics, and Environmental Education, 1-20.

Tobias, S. (1993). Overcoming math anxiety revised and expanded. New York: Norton.

Watts, B. K. (2011). Relationships of mathematics anxiety, mathematics self-efficacy and mathematics performance of Adult Basic Education students. Doctoral dissertation, CAPELLA UNIVERSITY.

Yaratan, H., \& Kasapoglu, L. (2012). Eight grade student's attitude, anxiety, and achievement pertaining to mathematics lessons. Procedia-Social and Behavioral Sciences, 46, 162-171. http://dx.doi.org/10.1016/j. sbspro.2012.05.087

\section{Copyrights}

Copyright for this article is retained by the author(s), with first publication rights granted to the journal.

This is an open-access article distributed under the terms and conditions of the Creative Commons Attribution license (http://creativecommons.org/licenses/by/3.0/). 